\title{
Portale społecznościowe jako narzędzie wpływu politycznego
}

\section{Wprowadzenie}

owe media są istotnym narzędziem oddziaływania na społeczeń-

stwo i politykę. Dotychczas zarówno publicyści, jak i przedstawiciele świata nauki, używając terminu "czwarta władza", mieli na myśli głównie prasę i telewizję. Dziś coraz częściej mówi się również o Internecie, podkreślając zwłaszcza funkcję kontrolną tego medium. W cyberprzestrzeni mamy do czynienia z zaawansowaną technologią zwaną potocznie Web 2.0, umożliwiającą użytkownikom coraz szersze uczestnictwo w wirtualnym świecie oraz podnoszącą rolę i znaczenie generowanych przez nich treści. Sieć staje się z dnia na dzień bardziej dostępnym i interaktywnym narzędziem, przez co daje wiele nowych możliwości, a co za tym idzie - jest wykorzystywana do realizacji innowacyjnych zadań, wypierając starsze media i w wielu sferach je zastępując. Nowe serwisy internetowe, pozwalające na wymianę opinii i multimediów, stają się bardzo popularne ze względu na atrakcyjność i przystępność, jak również silną promocję organizowaną przez firmy i stowarzyszenia skupione wokół współczesnych technologii [Hubert 2009: 20]. Interesujący jest jednakże fakt, że mimo rosnącego potencjału opiniotwórczego, mobilizacyjnego i kontrolnego Internetu, wpływ sieci w wielu środowiskach jest nadal bagatelizowany. 


\section{Przyczyny efektywności}

Najistotniejszą przyczyną popularności i wzrostu wykorzystania Internetu jest niewątpliwie postęp technologiczny. Ważny jest też coraz powszechniejszy i bardziej zaawansowany technologicznie dostęp do sieci oraz szereg nowych rozwiązań ułatwiających komunikację i docieranie do szerokiej rzeszy odbiorców. Możliwości Web 2.0 z dnia na dzień rosną i ewoluują w coraz bardziej zaawansowane technicznie formy, a jednocześnie stają się łatwiejsze w odbiorze dla laika, który jedynie z nich korzysta. Ponadto istotną rolę odgrywa specyficzna forma kontaktu, coraz częściej przybierająca formy interaktywne. Obecnie mamy do czynienia z wieloma mechanizmami i aplikacjami umożliwiającymi prowadzenie w sieci dialogu, wymianę zdań, komunikację polityczną oraz tworzenie reklam politycznych na zasadzie wzajemnej racji z odbiorcą. To wszystko zmienia w zasadniczy sposób charakter przekazu, ponieważ do tej pory spotykaliśmy się jedynie z komunikatem jednostronnym, obecnie zaś Internet tworzy przestrzeń zbiorowej łączności i debaty. Dyskusja może przybierać różne formy: efemerycznej wymiany zdań, burzliwych i wielowektorowych debat, sterowanych, sztucznych dyskusji albo umieszczania nieznaczących opinii na wybrany temat. Z jednej strony, o czym pisze Manuel Castells [2007: 37], poczta elektroniczna, witryny WWW, blogi, portale społecznościowe są używane do zabiegów marketingu politycznego bądź innych form manipulacji, z drugiej - istnieje szereg przejawów elektronicznej partycypacji obywatelskiej. Wraz z możliwościami komunikacyjnymi do cyberprzestrzeni przenosi się wiele innych sfer ludzkiego życia. Internet staje się źródłem powstania transgranicznych ruchów społecznych, wyrazem sprzeciwu i dezaprobaty, miejscem nawoływania do nieposłuszeństwa obywatelskiego czy towarzyskich rozmów o problemach społecznych. Mamy więc do czynienia z rozmaitymi zjawiskami wpisującymi się w nurt pozytywnej koncepcji cyberdemokracji. Jest to demokracja partycypacyjna, w której obywatel generuje wiele treści, uczestniczy w wirtualnych wspólnotach, a nawet wspiera cybernetyczny wolontariat. Z drugiej strony, wkraczamy w świat szczegółowego nadzoru i manipulacji obywatelem, jego preferencjami konsumenckimi i politycznymi, sterowania informacjami, które czyta bądź udostępnia w Internecie. Zarówno negatywne, jak i pozytywne skutki tego postępu są w znacznej mierze uwarunkowane przez kapitał kulturowy, finansowy i społeczny internautów oraz twórców przekazu. Zdaniem Tomasza Gobana-Klasa [2006: 143] 
„same techniki komunikacyjne nie mają bezpośredniego wpływu na zwyczaje i praktyki kulturalne".

W zależności od czynników społecznych, kulturowych i ekonomicznych aktywność polityczna w Internecie przejawia się w całym wachlarzu metod budowania wirtualnych kontaktów i form sieciowej relacji. Użytkownicy i otoczenie sieciowe stanowią zręby quasi-społeczeństwa, a nawet quasi-państwa - wolnego od realnej nadbudowy, z którą prowadzą dyskurs lub którą kontestują. To, jak zostaną wykorzystane nowe, interaktywne możliwości, dostarczane nam przez Web 2.0, w znacznej mierze zależy od potencjału internautów - obywateli, ich pomysłowości, ale też aktywności wykraczającej poza technorzeczywistość. To nie Internet - jako medium - tworzy nową arenę polityczną, ale ludzie posługujący się tym narzędziem. Poza tym po wirtualnym świecie poruszają się coraz większe rzesze użytkowników, intensywnie zwiększające swoją dynamikę. Chociaż zasięg nie jest tak masowy jak w przypadku telewizji, w wielu regionach świata już tylko nieliczni są wykluczeni cyfrowo. Nowe rozwiązania trafiają przede wszystkim do ludzi młodych, przez których Internet jest bardzo pozytywnie postrzegany i traktowany jako główne źródło informacji. Oprócz tego możemy zaobserwować wzrost liczby uczestników życia wirtualnego w pozostałych grupach wiekowych, a zwłaszcza wśród osób starszych, w wieku 55-65 lat [Facebook. Statystyki 2010].

Ponadto w sieci zostało też zlikwidowanych wiele barier przestrzennych i geograficznych. Krystalizuje się nowa tożsamość „obywatela świata", który uczestniczy w światowych ruchach społecznych i szuka internetowych, ponadnarodowych wspólnot reprezentujących jego poglądy. Tożsamość globalna przestaje być utopijnym konstruktem, jej wizja staje się coraz bardziej rzeczywista i objawia swoje nowe oblicze, które zmienia się $\mathrm{w}$ tak zawrotnym tempie, że trudno powiedzieć, w jakim kierunku będzie ewoluować.

\section{Portale społecznościowe}

Istotnym elementem wirtualnej przestrzeni są portale społecznościowe oraz związane z ich funkcjonowaniem mechanizmy i aplikacje. Szczególne zainteresowanie wzbudzają witryny z rozwiniętymi, interaktywnymi i urozmaiconymi programami, łączącymi różne funkcje. Do takiego typu portali można zaliczyć między innymi międzynarodowe serwisy: Facebook, 
Twitter, MySpace i Hi5, oraz polski Blip. Podstawą niniejszej analizy są dwa portale: Facebook i Twitter. Mimo że mają one różny charakter i funkcje, stały się przedmiotem rozważań prezentowanego artykułu, ponieważ zachodzące w ich ramach procesy i zjawiska społeczno-polityczne miały podobny przebieg.

Portal Facebook.com łączy przyjaciół, znajomych oraz członków rodziny i służy do podtrzymywania nawiązanych w realnym życiu kontaktów. Użytkownicy mogą wymieniać informacje, zdjęcia, dokumenty i linki, budować sieci zainteresowań, tworzyć narzędzia do komunikacji, gry i zabawy oraz korzystać z nich. Umożliwiają im to podstawowe aplikacje: Photos (zdjęcia), Notes (notatki), Groups (grupy), Events (wydarzenia) i Posted items (zamieszczone komentarze w postaci tekstu, linku bądź nagrania wideo, które widzą wszystkie osoby wpisane na listę znajomych właściciela konta), wyświetlane na stronie internauty, wraz z wszelkimi urządzeniami innych producentów, dodanymi przez niego do konta [Nations 2008]. Dzieje się to dzięki „ścianie”, na której oprócz zamieszczania wspomnianych wcześniej komentarzy i multimediów dochodzi często do wymiany zdań. Mike Westling [2007: 4] z Uniwersytetu Waszyngtońskiego pisze, że Facebook łączy w sobie i umieszcza w jednym miejscu najlepsze cechy lokalnego biuletynu, gazet oraz spotkań w ratuszu, ponieważ jest dostępny w każdej chwili praktycznie w dowolnym miejscu. Ogromną zaletą jest to, że w przeciwieństwie do rozmów w ratuszu, Facebook pozwala wszystkim członkom społeczności geograficznych na włączenie się do dyskusji na jakiś temat, zapewniając przy tym elastyczność podejmowania decyzji. Drugi ze wspomnianych portali, Twitter, umożliwia zamieszczanie krótkich wiadomości tekstowych, do 140 znaków, na zasadzie mikroblogowania. Notka napisana przez internautę w profilu w wyniku zalogowania na stronie głównej serwisu, przez wysyłanie SMS-a lub korzystanie z zewnętrznych aplikacji, pojawia się na stronach wszystkich pozostałych podłączonych do niego użytkowników [Nations 2008]. Oba portale mają bardzo wielu zarejestrowanych członków. Facebook, chociaż działa dopiero od 2004 roku, liczy 400 mln aktywnych użytkowników, z czego 70\% mieszka poza terytorium USA [Facebook. Statystyki 2010]. Średnio każdy z nich ma 130 "przyjaciół”, a oprócz tego na stronie portalu istnieje $160 \mathrm{mln}$ podmiotów, z którymi korzystający z serwisu wchodzą w interakcje. Założony w 2006 roku Twitter zgromadził do tej pory 75 milionów internautów (dane z kwietnia 2010 roku). 


\section{Podmioty funkcjonujące w obrębie portali}

Olbrzymie rzesze użytkowników szybko dostrzegły rozmaite grupy, które w różny sposób próbują wykorzystać portale do forsowania własnych interesów. Facebook został założony w akademiku przez studenta - Marka Zuckerberga, który początkowo nie przewidywał ani rozmachu swego projektu, ani tego, że do grona użytkowników, oprócz „przyjaciół”, dołączy szereg innych instytucji korzystających z dobrodziejstw kompatybilnego serwisu, pełnego najnowszych aplikacji. Pierwotnie Facebook miał jedynie pogłębiać uniwersyteckie znajomości i przyspieszyć wymianę informacji. Jednak nagle podmiotowość i moc oddziaływania uzyskało wiele niezależnych od siebie ośrodków. Oprócz przyjaciół i rodziny na portalu społecznościowym o kontakty z użytkownikiem zaczęły zabiegać partie i inne organizacje polityczne, grupy nacisku, serwisy informacyjne, prasa, telewizja, think tanki, organizacje pozarządowe, ruchy społeczne, a nawet „postacie historyczne" ${ }^{\prime \prime}$ i celebryci. Ich oddziaływanie przybiera obecnie różne formy: począwszy od kształtowania opinii odbiorców, wywierania wpływu na elektorat, marketingu politycznego, działań profrekwencyjnych, aż po pobudzanie otwartej debaty publicznej, przyczynianie się do rozwoju demokracji partycypacyjnej w Internecie i wyznaczanie nowego dyskursu politycznego. Co więcej, jest to wpływ specyficzny, odmienny z wielu względów jakościowych od wpływu politycznego w innych mediach.

\section{Wpływ polityczny}

Definiując politykę w ujęciu funkcjonalnym, jej zadania rozpatrujemy jako bodźce w systemie społecznym zapewniające jego rozwój przez rozstrzyganie konfliktów, artykulację, agregację i selekcję interesów, wychowanie polityczne oraz komunikację polityczną [Jabłoński 1991: 7]. Wpływ polityczny jest natomiast zamierzonym oddziaływaniem na sferę polityczną:

Zarówno przez uczestniczących w strukturach władzy, jak i przez podmioty niedysponujące władzą polityczną, lecz zabiegające w sposób świadomy, zorganizowany i aktywny o swe polityczne interesy. Podmio-

${ }^{1}$ Na portalu Facebook możemy zostać między innymi przyjaciółmi Karola Marksa i Józefa Piłsudskiego oraz fanami Platona, Che Guevary, Sørena Kierkegaarda czy Ludwika Zamenhofa. 
tami wpływającymi na zachowania innych, a i na decyzje władcze są zatem nie tylko posiadający władzę [...] ale i niedysponujący władzą, lecz wywierający na nią wpływ za pomocą legalnych i nielegalnych form, takich jak petycje, lobbing, manifestacje, strajki [Gulczyński 2007].

W obecnych czasach coraz więcej takich zachowań można zaobserwować na opisywanych powyżej witrynach społecznościowych.

Jedną z najczęstszych form aktywności na portalach jest budowanie sieci sympatyków, m.in. partii, ruchu, reformy, pomysłu. Grupy tematyczne są tworzone przez internautów i poruszają kwestie z bardzo wielu różnych dziedzin życia. Cechą szczególną jest to, że każda nowa osoba może zapraszać innych użytkowników do przyłączenia się. Członkowie grup mogą uczestniczyć w dyskusji, wymieniać linki, wysyłać wiadomości i najświeższe informacje. Przyłączanie się do konkretnej grupy w sieci może być wyrazem współodczuwania, sympatii czy przynależności do ruchu w realnym życiu. Ponadto owe działania służą sondowaniu i zastępują uliczne ankiety. W gazetach coraz częściej możemy przeczytać takie informacje: „32 tysiące użytkowników portalu Facebook jest przeciwko [...] 43 jest za [...]".

Wątpliwości dotyczą tego, czy mamy do czynienia z prawdziwym dyskursem politycznym. Na dodatek nie można w tej chwili dokonać jednoznacznej klasyfikacji nowych zjawisk, ponieważ są one bardzo dynamiczne i mają różne oblicza. Warto podkreślić, że portale stały się miejscem otwartego i asertywnego eksponowania poglądów politycznych przez prywatnych użytkowników, które nie zawsze łączy się z przenoszeniem aktywności i dyskusji poza sferę medialną. Tomasz Masłyk [2007: 265] słusznie zauważa, że:

Internet i towarzyszące mu technologie jest czynnikiem koniecznym, ale niewystarczającym dla budowania silnej demokracji opartej na deliberatywnych zasadach. Łatwo jednak - biorąc pod uwagę jego możliwości - ulec przekonaniu o jego sile i mocy sprawczej w oddziaływaniu na formę i treść działań społecznych. Tymczasem należy pamiętać o tym, że jest on jedynym narzędziem, które może w istotny sposób wzmacniać i promować aktywność obywatelską, a także skłaniać do udziału w procesie deliberatywnego - racjonalnego dyskursu politycznego.

Jak piszą Bernard Manin i Azi Lev-On [2009: 113], Internet jako medium stanowi „mieszane błogosławieństwo”. Z jednej strony, grupy w sie- 
ci są idealnym miejscem dla użytkowników o podobnych poglądach w tym przypadku istnieje jednak wysokie ryzyko zmniejszenia dyskusji i zignorowania przeciwstawnych punktów widzenia. Z drugiej strony, możemy zaobserwować takie grupy, które zapraszają do otwartej debaty na kontrowersyjne tematy, podczas gdy w tym samym czasie w bardzo niewielu dyskusjach w świecie rzeczywistym dopuszczani są do głosu przeciwnicy [Westling 2007: 4].

Należy zwrócić uwagę na specyficzny styl rozpowszechniania się informacji w Internecie. Sposób dystrybucji treści znacznie odróżnia to medium od innych nośników, tj. telewizji i prasy. Internauta poszukujący informacji sam wybiera źródło ich pochodzenia i przestaje być biernym konsumentem [Hubert 2009: 21]. Mając o wiele większy wpływ na wybór twórcy przekazu, bardziej ufa czytanym wiadomościom. Dysponuje też szerokim wachlarzem możliwości doboru swoich informatorów, co pozwala mu w większości przypadków na odnalezienie witryn odzwierciedlających jego poglądy. Wskutek tego nierzadko dochodzi do sytuacji, w której internauta skupia wokół siebie jedynie te źródła informacji, które odpowiadają jego oczekiwaniom. Wtedy szanse na zmianę przekonań są minimalne. Dochodzi do polaryzacji wcześniejszych założeń i ciągłego surfowania z dala od opinii odmiennych od własnych. Stąd też zwraca się większą uwagę na procesy umacniania poglądów i skupiania się wokół zwolenników niż na ich zmienianie.

Na konferencji zorganizowanej przez korporację Facebook jej wiceprezes - Blake Chandlee [2010] - zachęcając do reklamowania się na swoim portalu, podkreślał, że z badań marketingowych wynika, iż 78\% ludzi ufa rekomendacjom swoich przyjaciół, a zaledwie niewielki odsetek reklamom². Wydaje się, że ma to odniesienie nie tylko do wyborów konsumenckich, ale również wielu innych, w tym politycznych, a wysokie zaufanie oznacza zazwyczaj znaczny wpływ polityczny. Przenosząc to na arenę społeczno-polityczną, możemy z łatwością spostrzec, że news w Internecie rozpowszechnia się jak plotka - metodą kuli śnieżnej - osiągając coraz większe spektrum odbiorców. Mechanizmy przenoszenia wszelkich informacji w sieci funkcjonują podobnie jak w życiu prywatnym. Za każdym

2 Blake Chandlee to wiceprezes i dyrektor komercyjny, odpowiedzialny w firmie Facebook za działania w Europie, na Bliskim Wschodzie i w Afryce, który wystąpił na konferencji „Facebook Now" zorganizowanej przez serwis Facebook oraz marketingową Grupę ARBOinteractive 12 stycznia 2010 r. w Warszawie. Konferencja była poświęcona zagadnieniom merytorycznym związanym z reklamą na Facebooku. 
razem najczęściej zaglądamy do źródła dlatego, że zostało nam polecone przez znajomych. Niesie to za sobą zarówno pozytywne, jak i negatywne konsekwencje. Twórcy reklam korzystający z tego mechanizmu oraz szukający nowych sieci kontaktów nazywają go marketingiem szeptanym [Hughes 2008]. Jest on znakomitym instrumentem przenoszenia informacji drogą nieformalnych kontaktów, dającym złudzenie, że mamy do czynienia z prywatną opinią. Stworzona, iluzoryczna więź z odbiorcą ułatwia manipulacje.

Politycy zakładają swoje profile i strony w Internecie, skupiając swych sympatyków, którym nieustannie przypominają o oddaniu głosu oraz wzmacniają ich poglądy, budując wokół portali kapitał społeczny. Poza tym osoby publiczne, np. posłowie, lokalni politycy, publicyści, tworzą "kąciki prasowe online”, w których można odnaleźć bieżące informacje, obejrzeć najnowsze posty, zdjęcia, relacje z ważnych wydarzeń lub uczestniczyć w wirtualnej rozmowie [Leszczuk-Fiedziukiewicz 2009: 276]. Niewątpliwym plusem mediów społecznościowych jest duża niezależność w dostarczaniu informacji. Treść nie jest przetwarzana przez dziennikarzy, tylko bezpośrednio formułowana przez nadawców i w tej postaci dociera do internauty. „Większość tych internetowych form przekazu służy zmniejszeniu dystansu między wyborcą a politykiem i zwiększeniu konkurencyjności w komunikacji politycznej" [Leszczuk-Fiedziukiewicz 2009: 276]. Obserwatorzy profili piszą komentarze, wyrażając swoje nastroje polityczne. Niestety innowacje, oprócz pozytywnych skutków, takich jak większa dostępność do informacji, powodują, że wizerunek polityka jest podobny do kreacji gwiazdora, za którego obraz odpowiadają specjaliści. Nierzadko dzięki komentarzom internautów polityk interaktywnie uczy się, co i w jakim tonie ma mówić, by zyskać jak najszersze poparcie. W ten sposób dostaje się jednak w pułapkę „nastrojów chwili” $\mathrm{i}$ - w przypadku gdy jego podstawową motywacją polityczną jest chęć przypodobania się potencjalnemu "elektoratowi" - zamienia się w polityczny agregat rozproszonych komentarzy internautów. Tym samym wirtualne opinie mogą generować decyzje i postawy polityczne $w$ realnym świecie. Jest to o tyle groźne, że sieć w żadnym stopniu nie jest wyrazem opinii społeczeństwa jako całości, tylko pewnych jego segmentów czy zgoła przypadkowych często nastawionych kontestacyjnie do całej przestrzeni społeczno-politycznej - użytkowników Internetu.

Zebrani wokół polityka lub partii obywatele tworzą kapitał społeczny i mają potencjał partycypacyjny, w związku z czym wyłania się coraz wię- 
cej strategii zmierzających do tego, by go urzeczywistnić i wykorzystać. W celu zmaksymalizowania liczby odbiorców namawia się pozyskanych "fanów" do zapraszania innych znajomych i udostępniania informacji na prywatnych profilach. Ponieważ przeciętny użytkownik ma wielu „przyjaciół", ów zasięg może być ogromny i nieporównywalny z pozostałymi drogami komunikacji. W realnym życiu dzielimy się swoimi poglądami politycznymi jedynie z dobrymi znajomymi i rodziną, natomiast portal staje się sceną politycznego ekshibicjonizmu. Oprócz tego aktywność online przenosi się często do „życia offline”. W Polsce aktywizuje do działania między innymi profil „Powszechna mobilizacja na wybory prezydenckie" oraz „wydarzenie" ",Ratujmy program TVP Kultura".,ZZieramy głosy pod petycją. Powszechna mobilizacja na wybory" to strona działająca na zasadzie newslettera, z której na bieżąco wysyłane są nowe informacje, mające zmotywować użytkowników do działania. W przypadku wydarzenia mamy jedynie informację o problemie i formach, w jakich możemy wesprzeć konkretną akcję. Gdy ktoś chce wyrazić solidarność z wybranym przez siebie ruchem, może do niego dołączyć w przestrzeni wirtualnej i przez to również pośrednio zamanifestować swój pogląd, ponieważ informacja o wstąpieniu do danej grupy pojawia się na stronie profilowej użytkownika i w bezpośrednio aktualizowanych zawiadomieniach u wszystkich jego znajomych.

Za najlepszą i najskuteczniejszą promocję polityczną w Internecie jest uznawana kampania prezydencka Baracka Obamy. Oprócz stosowania marketingu politycznego w samej sieci prosił on lokalne środowiska internautów o pomoc w organizacji kampanii. Budując najpierw intensywną relację z odbiorcami, a potem dokonując wielu zabiegów aktywizujących, wzbudził zaangażowanie i realne działania ludzi, które przyczyniły się do jego wygranej. W tym celu wykorzystał wszelkie możliwości, by przedstawić w pozytywnym świetle swój wizerunek. Amerykanie byli z nim „na Ty" na bardzo wielu portalach społecznościowych. Mogli na nich oglądać jego zdjęcia, filmy pokazujące nie tylko jego życie polityczne, ale także prywatne oraz czytać komentarze polityczne. Bardziej dociekliwi zaglądali na stronę internetową www.barackobama.com, słuchali podcastów ${ }^{3} z$ wywiadami i byli dołączani do listy mailingowej. Obecnie kampanię Obamy naśladuje bardzo wielu polityków na całym świecie, zarówno w rozwiniętych demokracjach, jak i w państwach o nieustabilizowanych

${ }^{3}$ Forma internetowego zapisu dźwięku, umożliwiająca szybkie dotarcie do różnych nagrań, w tym wielu archiwalnych audycji radiowych. 
mechanizmach politycznych. Na Facebooku i Twitterze, oprócz polityków z niemal każdego państwa europejskiego, możemy spotkać się z kampanią prezydencką ze Sri Lanki czy z politykami z Ruandy.

Jeszcze bardziej spektakularne i łatwiejsze do zaobserwowania rezultaty widać w takich państwach, jak Iran i Mołdawia. W tych dwóch miejscach młodzi ludzie wyszli na ulice, mobilizowani na zachodnich portalach internetowych przez lokalnych aktywistów. Serwisy Twitter i Facebook stanowią doskonałe medium służące do nagłaśniania problemów społecznych i dzięki ich pomocy w Teheranie i Kiszyniowie wiosną 2009 roku na miejskich placach pojawiły się tłumy młodych protestujących [Iran. Wojna w Internecie 2009]. W obu przypadkach studenci używali Twittera oraz Facebooka jako forum szybkiej wymiany komunikatów. Dzięki komputerom i mobilnemu Internetowi informowali się o przebiegu organizowanych demonstracji. Zagraniczna prasa określała najpierw wydarzenia w Mołdawii, a potem w Teheranie jako Twitter revolution [Morozov 2009]. Zjawisko to na bieżąco opisuje Evgeny Morozov [2009] na łamach „Foreign Policy”. Dnia 7 kwietnia 2009 roku sprawdził on najbardziej popularny temat dyskusji na Twitterze w ciągu ostatnich 48 godzin. Najwięcej osób w globalnej sieci obserwowało i publikowało posty oznaczone dziwnym tagiem „\# pman, obok takich jak Eminem i Wielkanoc".,Pman” jest skrótem od Piata Marii Adunari Nationale, nazwy największego placu w Kiszyniowie, stolicy Mołdawii, na którym odbywały się antyrosyjskie protesty [Morozov 2009]. Mimo innego kontekstu politycznego podobnie wygląda sytuacja w Iranie. Po tragicznej śmierci szesnastoletniej Nedy, irańskiej dziewczyny zastrzelonej przez policję podczas opozycyjnej demonstracji, na Twitterze i Facebooku pojawiły się tysiące identycznych wpisów: „Spoczywaj w spokoju Neda. Świat płacze, patrząc na Twoje ostatnie tchnienie, lecz nie zginęłaś na darmo" [16-letnia Neda... 2009]. Nie jest to jedyne wydarzenie, które zostało nagłośnione przez internautów, a jedynie kropla w morzu informacji, które zamieszczają młodzi „cyberaktywiści”.

Internet i portale społecznościowe stały się miejscem dyskusji i poruszania kwestii, które z wielu względów są ignorowane przez inne media, oraz tworzenia się nowych sfer otwartego dyskursu politycznego. W interaktywnych społecznościach rodzą się różnorodne ruchy społeczne. Dzieje się tak między innymi dzięki niskim kosztom ponoszonym przez nadawców i odbiorców, współwystępowaniu komunikacji poziomej i pionowej, istnieniu współodpowiedzialności za treści, promowaniu równości, bardzo dużej prędkości rozpowszechniania się informacji oraz nieistnieniu granic. 
Są to niewątpliwe korzyści płynące z zastosowania Internetu w polityce demokratycznej [McQuail 2007: 165], które ją umacniają i rozwijają w zupełnie innym kierunku niż dotychczas. Dzięki temu można zaobserwować wiele przejawów deliberacji, które są zauważalne przez dłuższy okres. Już na początku lat 90. w Santa Monica w Kalifornii toczyła się burzliwa internetowa dyskusja o problemie bezdomności. Co więcej, wzięli w niej udział wirtualnie sami bezdomni. Dziś podobne debaty można spotkać na każdym kroku. Internetowe rozmowy są prowadzone przez członków ruchów społecznych, politycznych, obywateli skupionych wokół konkretnych instytucji oraz grup przyjaciół. Szczególnym ułatwieniem na portalu Facebook jest zespolenie wszystkich źródeł informacji na jednej stronie. Od niedawna internauta nie musi codziennie zaglądać na wiele witryn, które go interesują, ponieważ część z nich jest podłączona do serwisu społecznościowego. Dzięki temu na ścianie użytkownika pojawiają się wszystkie nowości. Skutkuje to tym, że do odbiorcy dociera o wiele więcej informacji niż w sytuacji, gdyby miał odwiedzać każdą stronę z osobna.

Kształtują się również zupełnie nowe sfery dyskusji. Na stronach Facebooka i Twittera są bowiem poruszane kwestie, o których milczą inne media. Na łamach poszczególnych grup na Facebooku można przeczytać o karze śmierci w Iranie (np. „I bet I can find 1,000,000 Against Government Violence in Iran" lub "In Defense of Freedom of Speech in Iran"), zamieszkach w Palestynie albo poszukać kontrowersyjnych, nieoficjalnych opinii na temat wypadku w Smoleńsku. Dyskusje toczą się nie tylko wśród zwolenników jakiegoś poglądu, ale również między oponentami, zwłaszcza jako reakcja na posty czasopism, dzienników czy publicystów. Często dochodzi do niezamierzonej konfrontacji przekonań na profilach osób, które mają w gronie swych znajomych internautów o innych zapatrywaniach. Dzięki nowym technologiom czasami wystarczy jeden post, by wzbudzić silny rezonans użytkowników sieci. Na przykład z pozoru nieznaczący projekt nastoletniej dziewczyny z Polski, która założyła grupę na Facebooku o nazwie „Mówię stanowcze nie zburzeniu Pałacu Kultury”, w ciągu zaledwie dwóch tygodni zgromadził ponad 8,5 tysiąca "fanów", a obecnie, po pół roku istnienia w sieci (dane z kwietnia 2010 roku), ponad 17,5 tysiąca [Facebook. Statystyki 2010]. Dzięki szybkiemu tempu rozpowszechniania się informacji grupy te stanowią silne zaplecze mobilizacyjne i czynią Internet podstawowym narzędziem komunikacji. 


\section{Wnioski}

Medium może stanowić każdy. W przypadku prasy jest nim dziennikarz prasowy, telewizji - dziennikarz telewizyjny itd. W tej sytuacji bardzo trudno stwierdzić, kto odpowiada za rozpowszechniane w sieci informacje. Może to być nasz znajomy z pracy, wariat z okolicy, dziennikarz, intelektualista, polityk albo po prostu specjalista od marketingu. Niepokojące jest to, że często nie jesteśmy w stanie skontrolować, z kim mamy do czynienia. Wiemy to, kiedy czytamy post kolegi, ale nigdy nie rozstrzygniemy, kto kryje się za profilem polityka czy celebryty. Ponadto istnieje duże przyzwolenie społeczne na różne formy manipulacji, ukrytej reklamy, na tworzenie pozornych ruchów oddolnych i inicjatyw. W gruncie rzeczy zwykły odbiorca, jeśli jest świadomy owych zabiegów, może czuć się zagubiony, natomiast jednostka niezdająca sobie z nich sprawy łatwiej ulega wpływom. Coraz częściej na portalach są podejmowane pozornie spontaniczne inicjatywy, organizowane akcje poparcia dla jakiejś idei, polityka, działania, decyzji bądź sprzeciwu wobec nich, które mają sprawiać wrażenie inicjatyw oddolnych. Takie praktyki marketingowe, określane przez Amerykanów jako astroturfing, od nazwy sztucznej trawy, jako odniesienie do grassroots movement, czyli społecznych ruchów oddolnych, budzą wiele kontrowersji i pytań o aspekt etyczny. Wielowymiarowy charakter portali społecznościowych sprawia, że należy wnikliwie i interdyscyplinarnie przyjrzeć się ich istocie oraz rządzącym nimi mechanizmom. Jedynie dogłębne poznanie problemu pozwoli zrozumieć ten fenomen społeczny. Proces informatyzacji przebiega w zawrotnym tempie, stanowiąc jeden z najważniejszych motorów zmiany naszej cywilizacji. Dziś już mało kto wyobraża sobie surfowanie po Internecie bez wyszukiwarki Google, choć powstała ona zaledwie 7 lat temu. Najszybciej rozwijające się medium w historii świata - radio - osiągnęło liczbę $50 \mathrm{mln}$ użytkowników w ciągu 38 lat, Internet potrzebował 4 lat, natomiast Facebook zgromadził $100 \mathrm{mln}$ członków w ciągu 9 miesięcy [Chandlee 2010]. Dane te doskonale obrazują szybkość przeobrażeń społecznych, które należy dokładnie obserwować i badać, by lepiej rozumieć ich społeczne i polityczne konsekwencje. 


\section{Bibliografia}

Castells Manuel. 2007. Społeczeństwo sieci. Warszawa: Wydawnictwo Naukowe PWN.

Goban-Klas Tomasz. 2006. Media i komunikowanie masowe. Teorie i analizy prasy, radia, telewizji i Internetu. Warszawa: Wydawnictwo Naukowe PWN.

Hubert Wit. 2009. Cyfrowe nierówności w dobie kultury 2.0. Problemy wybrane. [W:] M. Jeziński (red.). Nowe media a media tradycyjne. Toruń: Wydawnictwo Adam Marszałek.

Hughes Mark. 2008. Marketing szeptany. Buzz marketing. Z ust do ust. Jak robić szum medialny wokół siebie, firmy, produktu. Warszawa: Wydawnictwo MT Biznes.

Jabłoński Andrzej. 1991. Polityka. Interpretacje definicyjne. [W:] A. W. Jabłoński, L. Sobkowiak (red.). Kategorie analizy politologicznej. Wrocław: Wydawnictwo Uniwersytetu Wrocławskiego.

Leszczuk-Fiedziukiewicz Anna. 2009. Kampania negatywna i kampania internetowa jako przykład promocji polityków w kampanii wyborczej do Parlamentu Europejskiego w 2009 roku. [W:] E. Kużelewska, A. R. Bartnicki (red.). Zachód w globalnej i regionalnej polityce międzynarodowej. Toruń: Wydawnictwo Adam Marszałek.

Manin Bernard, Lev-On Azi. 2009. Happy accidents: Deliberation and online exposure to opposing views. [W:] T. Davies, S. Gangadharan (red.). Online Deliberation: Design, Research and Practice. Chicago: Center for the Study of Language and Information.

Masłyk Tomasz. 2007. Demokracja deliberatywna a Internet. [W:] M. Szpunar (red.). Media a polityka. Rzeszów: Wydawnictwo Wyższej Szkoły Informatyki i Zarządzania.

McQuail Denis. 2007. Teoria komunikowania masowego. Warszawa: Wydawnictwo Naukowe PWN.

\section{Źródła internetowe}

Facebook. Statystyki. 2010. http://www.facebook.com/press/info.php?statistics, 13.04.2010.

Gulczyński Mariusz. 2007. Władza polityczna. http://knol.google.com/k/władza-polityczna\#, 19.04.2010.

Iran. Wojna w Internecie. Facebook i Twitter za Teheranem. 2009. http://www.redak- 
cja.newsweek.pl/Tekst/Polityka-Polska/530070,Iran---wojna-w-interneciefacebook-i-twitter-za-teheranem.html, 1.05.2010.

Morozov Evgeny. 2009. Moldova's Twitter revolution. http://neteffect.foreignpolicy. com/posts/2009/04/07/moldovas_twitter_revolution, 12.04.2010.

Nations Daniel. 2008. What is a Tweet. http://webtrends.about.com/od/glossary/g/ what-is-a-tweet.htm, 1.05.2010.

16-letnia Neda. Męczennica irańskiej rewolucji. 2009. http://wiadomosci.gazeta.pl/ Wiadomosci/1,80591,6741791,16_letnia_Neda_meczennica_iranskiej_rewolucji.html, 28.04.2010.

Westling Mike. 2007. Expanding the Public Sphere: The Impact of Facebook on Political Communication. http://www.thenewvernacular.com/projects/facebook and_political_communication.pdf, 4.05.2010.

\section{Inne źródła}

Chandlee Blake. 2010. Przyszłość mediów społecznościowych w Polsce. Referat wygłoszony na konferencji „Facebook Now”. Warszawa, 12 stycznia 2010. 